\title{
Perancangan Aplikasi Pencatatan Data Manifes Penumpang Kapal Penyeberangan Danau Toba Menggunakan Web
}

\author{
Tantri Hidayati Sinaga \\ ${ }^{1}$ Fakultas Teknik dan Komputer, Prodi Sistem Informasi, Universitas Harapan Medan, Medan, Indonesia \\ Email: tantri.hida83@gmail.com
}

\begin{abstract}
Abstrak-Kawasan Wisata Danau Toba, memiliki potensi wisata alam yang terbentuk dari aktifitas Supervulkanik sehingga menjadikannya sebagai salah satu objek wisata favorit di Indonesia. Kapal penyeberangan merupakan transportasi utama di kawasan pariwisata Danau Toba dan menjadi pilihan favorit masyarakat di sekitar Danau Toba maupun wisatawan yang ingin berkunjung ke Pulau Samosir. Data Manifes Penumpang merupakan dokumen yang sangat penting dalam proses perjalanan transportasi, khususnya pesawat terbang dan kapal laut, termasuk kapal penyeberangan di Danau Toba. Manifes memuat data penumpang, awak kapal berikut dengan pelbagai barang yang diangkut oleh moda transportasi tersebut. Dokumen manisfes juga bermanfaat untuk proses pencairan asuransi untuk kecelakaan transportasi. Data Manifes penumpang menggunakan kapal penyeberangan di Danau Toba saat ini hanya mencatat jumlah penumpang dan jumlah kendaraan yang menaiki kapal, namun tidak mencatat nama penumpang. Aplikasi pencatatan data manifest penumpang dibutuhkan untuk mengelola data manifes penumpang kapal penyeberangan di Danau Toba, dengan tujuan untuk mempermudah pemantauan kegiatan penyeberangan dan proses identifikasi penumpang kapal penyeberangan. Penelitian ini akan menghasilkan aplikasi pencatatan Manifest Penumpang Kapal Penyeberangan di Danau Toba. Aplikasi yang dibuat berbasis web, sehingga akan mudah diakses dimana saja, dan hanya dapat diakses oleh Dinas Perhubungan Sumatera Utara. Aplikasi ini dapat digunakan untuk mempermudah pihak terkait dalam melakukan pengawasan dan pengontrolan terhadap daftar penumpang kapal yang melakukan perjalanan di Danau Toba, sehingga akan dapat mengurangi resiko kecelakaan dan penyalahgunaan jumlah muatan kapal dari yang diizinkan.
\end{abstract}

Kata Kunci: Manifes, Kapal Penyeberangan, Danau Toba, e-manifes

Abstract-Lake Toba Tourism Area, has the potential for natural tourism which is formed from super volcanic activities so that it makes it one of the favorite tourist attractions in Indonesia. The crossing ship is the main transportation in the Lake Toba tourism area and is a favorite choice for people around Lake Toba and tourists who want to visit Samosir Island. Passenger Manifest Data is a very important document in the process of transportation, especially airplanes and ships, including crossing ships on Lake Toba. The manifest contains data on passengers, crew members and various items transported by the mode of transportation. Manifest documents are also useful for the process of disbursing insurance for transportation accidents. Passenger Manifest data using crossing ships on Lake Toba currently only records the number of passengers and the number of vehicles riding the ship, but does not record the name of the passenger. Passenger manifest data application is needed to manage the manifest data of crossing ship passengers on Lake Toba, with the aim of facilitating monitoring of crossing activities and the process of identifying passenger crossing vessels. This research will produce an application to recording Passenger Manifest of crossing ship in Lake Toba. The application is based on web, so it will be easily accessed anywhere, and can only be accessed by the North Sumatra Transportation Office. This application can be used to make it easier for the parties involved in supervising and controlling the list of ship passengers who travel on Lake Toba, so that it can reduce the risk of accidents and misuse of the number of boat loads from the permit.

Keywords: Manifest, Crossing Ship, Lake Toba, e-manifes

\section{PENDAHULUAN}

Manifes adalah daftar isi muatan yang diangkut kapal, yang memuat jumlah merek dan nomor barang muatan, nama pengirim, serta alamat yang dituju; konosemen; surat muatan[1]. Manifest Keberangkatan Sarana Pengangkut yang selanjutnya disebut outward manifest adalah daftar barang niaga yang diangkut oleh sarana pengangkut melalui laut, udara dan darat pada saat meninggalkan Kawasan Pabean[2].

Dokumen ini pada dasarnya bermanfaat bagi maskapai atau jasa angkutan laut untuk memeriksa kelengkapan penumpang. Dokumen ini bersifat rahasia atau terbatas mengingat memuat data pribadi penumpang. Manifest akan memuat daftar nama setiap penumpang yang berangkat pada satu penerbangan atau pemberangkatan kapal laut.

Dalam pengembangan kawasan pariwisata, Danau Toba merupakan salah satu dari 88 yang termasuk ke dalam Kawasan Strategis Pariwisata Nasional (KSPN) berdasarkan Peraturan Pemerintah Nomor 50 Tahun 2011 tentang Rencana Induk Pembangunan Kepariwisataan Nasional Tahun 2010-2025, sehingga menjadi prioritas dalam pembangunan kepariwisataan. Berdasarkan Undang-Undang Nomor 10 Tahun 2009, Kawasan Strategis Pariwisata adalah kawasan yang memiliki fungsi utama pariwisata atau memiliki potensi untuk pengembangan pariwisata yang mempunyai pengaruh penting dalam satu atau lebih aspek, seperti pertumbuhan ekonomi, sosial dan budaya, pemberdayaan sumber daya alam, daya dukung lingkungan hidup, atau pertahanan dan keamanan. Terkait pengembangan kawasan pariwisata Danau Toba sebagai kawasan pariwisata prioritas khususnya pada bagian wilayah Kabupaten Toba Samosir terdapat peraturan pariwisata yang mendukung pengembangan kawasan ini, yaitu Peraturan Presiden Nomor 81 Tahun 2014 tentang Rencana Tata Ruang Kawasan Danau Toba dan Sekitarnya. Peraturan tersebut berisikan tentang aspek pembangunan dan pengembangan kawasan pariwisata Danau Toba[3]. 
Kepariwisataan Danau Toba memiliki potensi wisata alami danau, wisata geopark atau taman bumi dan wisata budaya daerah (Batak). Destinasi Wisata Nasional ini menjadi salah satu unggulan dalam daya saing industri pariwisata nasional, bahkan internasional sehingga menjadi salah satu amanat pembangunan pariwisata nasional melalui Nawacita dan masuk dalam 10 Destinasi Wisata Nasional. Kawasan Wisata Danau Toba memiliki potensi wisata alam yang terbentuk dari aktifitas Supervulkanik sehingga menjadikannya sebagai geopark atau taman bumi, Penetapan warisan taman bumi (geopark) oleh UNESCO merupakan bentang pemandangan alam berupa geoarea[4].

Angkutan Penyeberangan adalah angkutan yang berfungsi sebagai jembatan yang menghubungkan jaringan jalan dan/atau jaringan jalur kereta api yang dipisahkan oleh perairan untuk mengangkut penumpang dan kendaraan beserta muatannya [5].

Kapal penyeberangan merupakan transportasi utama di kawasan pariwisata Danau Toba dan menjadi pilihan favorit masyarakat di sekitar Danau Toba maupun wisatawan yang ingin berkunjung ke Pulau Samosir. Data Manifes penumpang menggunakan kapal penyeberangan di Danau Toba saat ini hanya mencatat jumlah penumpang dan jumlah kendaraan yang menaiki kapal, namun tidak mencatat nama penumpang. Laporan yang disajikan hanya berupa rekapitulasi daftar perjalanan kapal dan daftar muatan kapal secara umum, sehingga tingkat keakuratan data yang dihasilkan akan sangat diragukan kebenarannya.

Adanya penumpang dengan jumlah lebih dari 150 penumpang serta pemuatan kendaraan sekitar 70 unit di atas kapal merupakan dampak dari fungsi pengawasan yang tidak berjalan dengan baik di pelabuhan penyeberangan Danau Toba. Setidaknya ada dua hal yang hilang dalam sistem pemuatan penumpang pada pelayaran Danau Toba, yaitu tiket — terkait dengan retribusi daerah dan premi asuransi kecelakaan — dan daftar penumpang (manifes).Manifes penumpang yang jelas akan memberikan detail jumlah penumpang beserta identitasnya. Sistem pencatatan yang tidak terlaksana di perairan Danau Toba menyebabkan ketidakjelasan jumlah, nama, alamat, dan usia penumpang yang menjadi penumpang kapal penyeberangan. Daftar orang hilang yang dilaporkan oleh keluarga dan kerabat yang merasa orang terdekatnya hilang dalam pelayaran Sinar Bangun 4 merupakan contoh kesimpangsiuran daftar penumpang pada penyeberangan di Danau Toba. Tanpa adanya daftar muatan, siapa saja yang ikut di dalam pelayaran tersebut tidak dapat dipastikan secara jelas, kecuali setelah ditemukan dengan selamat atau jenazahnya dapat dipastikan.

Daftar penumpang juga memberikan kepastian mengenai kapasitas kapal. Kondisi kapal-kapal di Danau Toba yang tidak memiliki garis lambung timbul menyulitkan pengawas untuk menentukan apalah suatu kapal mengalami kelebihan muatan atau tidak, kecuali mengandalkan jumlah maksimal penumpang yang diperbolehkan [6].

Berdasarkan masalah dan contoh kasus diatas, dibutuhkan sebuah aplikasi untuk mengelola data manifes penumpang kapal penyeberangan di Danau Toba untuk mempermudah pemantauan kegiatan penyeberangan dan proses identifikasi penumpang kapal penyeberangan, khususnya di Kawasan Danau Toba. Aplikasi yang dirancang harus dapat diakses dengan mudah dengan berbagai perangkat, kapan saja dan dimana saja, sehingga akan membantu pihak terkait untuk melakukan pendataan.

\section{METODE PENELITIAN}

\subsection{Langkah Penelitian}

Penelitian perancangan aplikasi data manifes penumpang ini membutuhkan beberapa langkah dan tahapan untuk proses pengerjaannya. Berikut ini adalah gambar dari langkah-langkah penelitian ini.

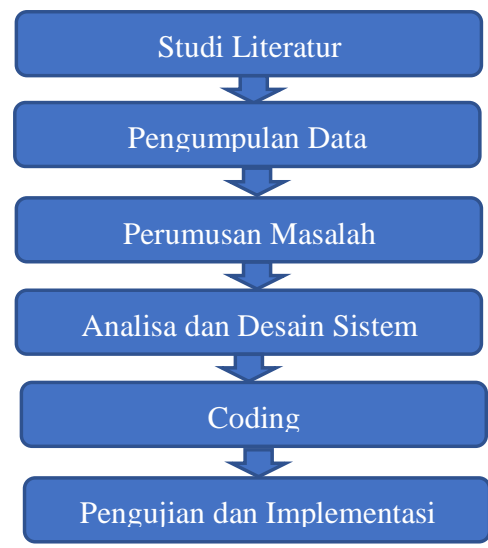

Gambar 1. Langkah Penelitian

Dalam melakukan penelitian ini, terdapat beberapa tahapan yang dilakukan, yaitu:

a. Studi Literatur 
Mempelajari literatur yang berkaitan dengan teori manifest penumpang, sistem informasi transportasi dan kapal penyeberangan, sumber literatur diambil dari jurnal, buku teks, paper, karya ilmiah, dan situs-situs penunjang lainnya.

b. Pengumpulan Data

Pada tahap ini pengumpulan data dilakukan dengan cara langung observasi serta mengumpulkan data-data pencatatan manifes penumpang pada Dinas Perhubungan Sumatera Utara dan kemudian dipelajari, mencari dan memutuskan masalah-masalah yang akan dipecahkan, diambil berdasarkan ruang lingkup penelitian, dimana masalah yang dihadapi berkaitan dengan pembuatan desain aplikasi pencatatan manifes penumpang kapal penyeberangan.

c. Perumusan Masalah

Setelah tahap pengumpulan data dilakukan, langkah selanjutnya adalah membuat perumusan masalah yang berkaitan dengan permasalahan yang dihadapi. Bagaimanakah membuat desain aplikasi pencatatan manifes penumpang kapal penyeberangan..

d. Analisa dan Desain Sistem

Pada tahap ini dilakukan analisa-analisa dalam proses pembuatan desain aplikasi pencatatan manifes penumpang kapal penyeberangan, bagaimanakah pengujian dilakukan terhadap analisis yang akan digunakan, sampai tahap implementasi. Setelah masalah-masalah tersebut dapat didefinisikan, pendekatanpendekatan dipilih berdasarkan literatur dari berbagai sumber seperti buku teks dan internet tentang metodemetode yang sedang digunakan saat ini yang akan digunakan dan dipilih untuk menyelesaikan permasalahan.

e. Coding

Pada tahap ini akan dilakukan proses pembuatan coding setelah melalui tahapan analisa dan desain sistem.

f. Pengujian dan Implementasi

Pada tahap ini dilakukan proses pengujian dari desain yang telah dibuat dengan ditampilkan dalam bentuk aplikasi web, yang nantinya akan menggambarkan hasil desain aplikasi secara keseluruhan.

\subsection{Proses Pencatatan Data Manifest Penumpang Kapal Penyeberangan}

Proses pendataan manifes penumpang saat ini dilakukan dengan melakukan input rekap data dengan menggunakan aplikasi excel. Adapun proses pencatatan data penumpang kapal penyeberangan Danau Toba selengkapnya adalah sebagai berikut:

\section{PROSES PENCATATAN DATA MANIFEST KAPAL PENYEBERANGAN DANAU TOBA}

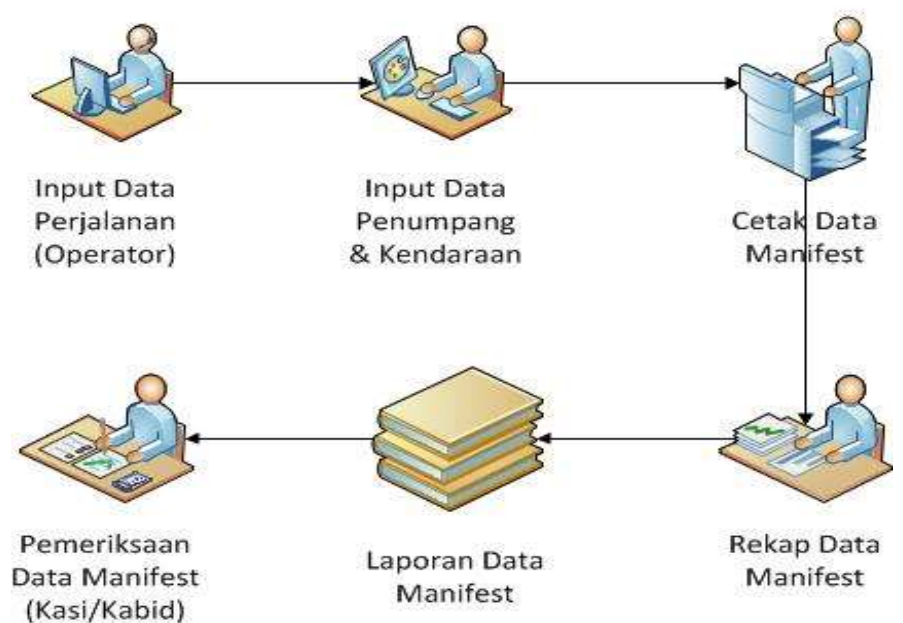

Gambar 2. Proses Pencatatan Data Manifes Kapal Penyeberangan Danau Toba

Dari gambar diatas dapat dilihat bahwa proses pencatatan manifes diawali dengan input data perjalanan dan data penumpang oleh operator dengan menggunakan aplikasi excel. Selanjutnya data tersebut akan dicetak dan akan direkap pada setiap harinya. Hasil Rekapitulasi akan dilaporkan setiap bulan kepada Kepala Bidang di Dinas Perhubungan.

Penelitian ini akan melakukan perancangan aplikasi pendataan manifes penumpang kapal penyeberangan Danau Toba menggunakan web untuk menggantikan proses pencatatan saat ini. Aplikasi yang dihasilkan diharapkan akan membantu proses pencatatan manifest dengan lebih mudah dan lebih detail, sehingga laporan yang dihasilkan akan membantu pihak terkait dalam melakukan pencadataan penumpang secara akurat dan cepat. 


\section{HASIL DAN PEMBAHASAN}

\subsection{Pemodelan UML}

Untuk mempermudah proses perancangan sistem, maka dilakukan pemodelan sistem dengan menggunakan UML. Unified Modeling Language (UML) yang dikeluarkan oleh Object Management Group (OMG), adalah bahasa grafis dan telah diterima secara luas sebagai cara standar untuk pemodelan sistem perangkat lunak berorientasi objek. Hal ini juga dapat diterapkan untuk pemodelan proses bisnis dan perangkat keras arsitektur sistem dan desain[7].

\section{a. Use Case Diagram Website Data Manifes Penumpang Kapal}

Use case diagram atau diagram use case menggambarkan kelakuan (behavior) dari sistem informasi yang akan dibuat. Use case diagram umumnya digunakan untuk menjelaskan interaksi antara satu atau lebih aktor dengan sistem informasi yang akan dibuat. Use case diagram digunakan untuk mengetahui fungsi apa saja yang ada di dalam sebuah sistem dan siapa saja yang memiliki hak akses untuk menggunakan fungsi-fungsi tersebut. Use case diagram pada website Data Manifes Penumpang Kapal dapat dilihat pada gambar berikut :

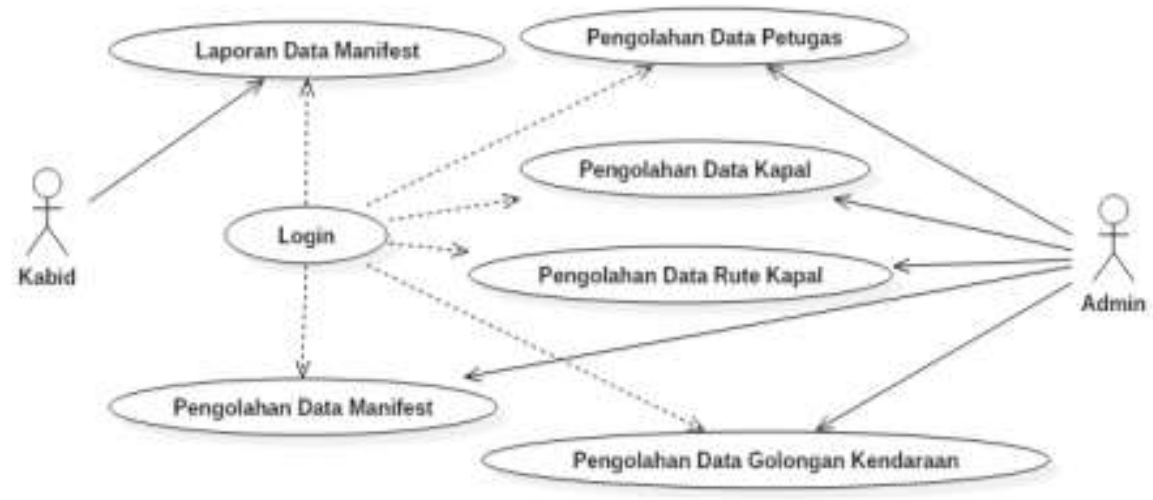

Gambar 3. Use case Diagram Website Pencatatan Data Manifest Penumpang Kapal Penyeberangan

\section{b. Desain Sequence Diagram}

Dalam sequence diagram ini terlihat untuk memperjelas proses sistem secara keseluruhan dan memaparkan penjelasan yang ada pada diagram use case sebelumnya

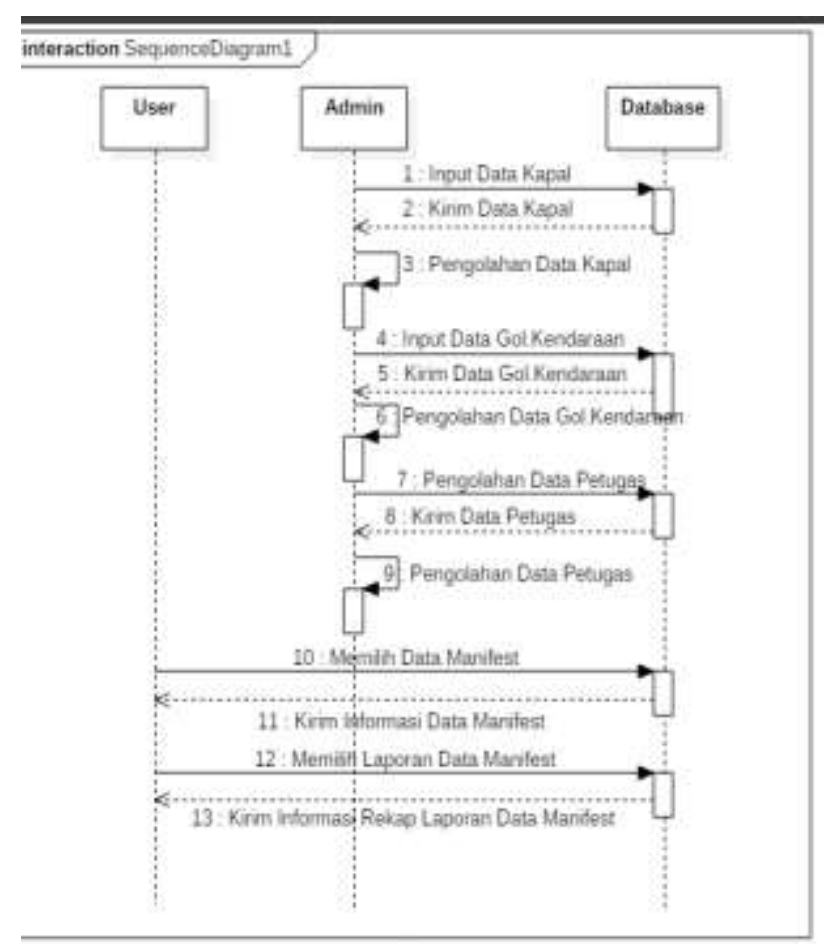

Gambar 4. Sequence Diagram Keseluruhan Sistem 
JURNAL MEDIA INFORMATIKA BUDIDARMA

Volume 4, Nomor 1, Januari 2020, Page 237-244

ISSN 2614-5278 (media cetak), ISSN 2548-8368 (media online)

Available Online at https://ejurnal.stmik-budidarma.ac.id/index.php/mib

DOI $10.30865 /$ mib.v4i1.1892

\section{c. Desain Activity Diagram}

Ada beberapa aktifitas yang dikerjakan pada use case dari pencatatan data manifest penumpang kapal penyeberangan berbasis web seperti terlihat pada gambar berikut.

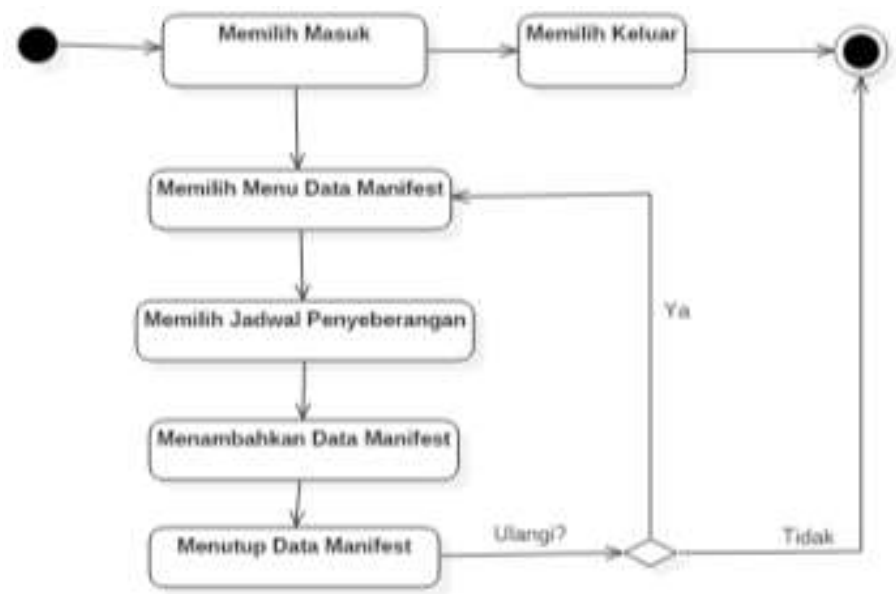

Gambar 5. Activity Diagram Pencatatan Manifes Penumpang

\section{d. Desain Deployment Diagram}

Di dalam pencatatan data manifes penumpang kapal penyeberangan ini sedianya akan dibangun dengan sistem online. Konstruksi Fisik dari Sistem Pencatatan Data Manifes Penumpang Kapal Penyeberangan ini terlihat di dalam gambar berikut.

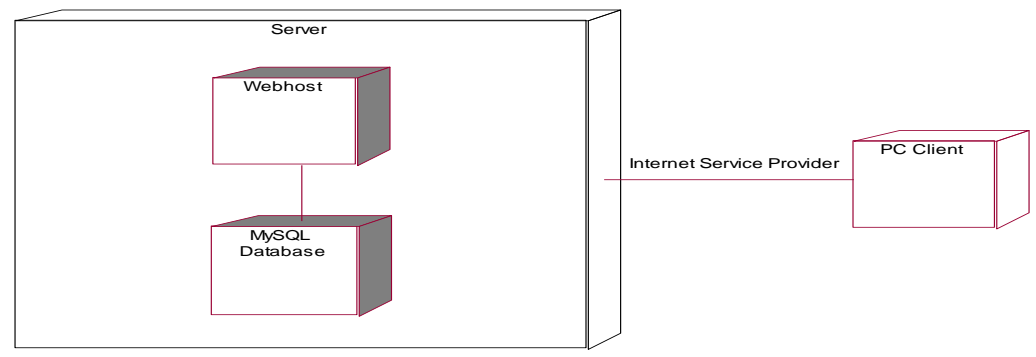

Gambar 6. Deployment Diagram Implementasi Sistem

\subsection{Implementasi}

Untuk memperjelas bentuk dari implementasi antarmuka dari sistem aplikasi pencatatan manifest kapal penyeberangan, berikut ini beberapa tampilan form utama dari program yang telah dibuat.

\section{Halaman Login}

Halaman ini digunakan untuk proses identifikasi pengguna yang ingin memasuki sistem aplikasi manifes kapal. Pengguna yang ingin masuk harus memiliki akun yang telah disetujui oleh admin sistem.

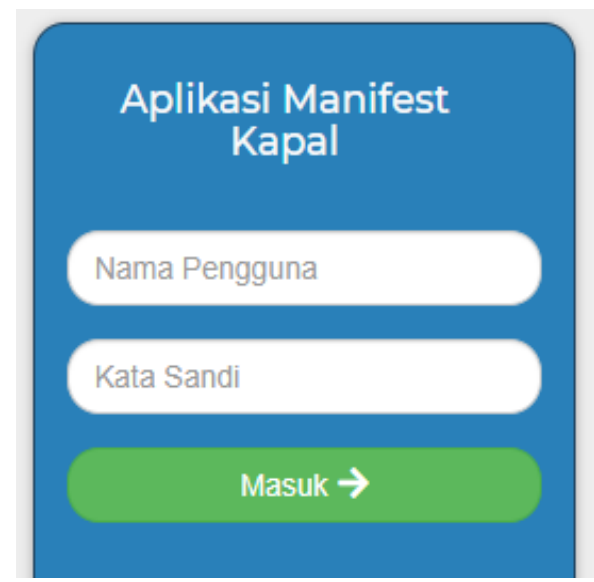

Gambar 7. Halaman Login 
JURNAL MEDIA INFORMATIKA BUDIDARMA

Volume 4, Nomor 1, Januari 2020, Page 237-244

ISSN 2614-5278 (media cetak), ISSN 2548-8368 (media online)

Available Online at https://ejurnal.stmik-budidarma.ac.id/index.php/mib

DOI $10.30865 /$ mib.v4i1.1892

\section{Halaman Menu Utama}

Halaman ini merupakan dashboard menu utama dari sistem. Pengguna dapat melakukan akses ke semua proses input data hingga mencetak laporan melalui halaman ini.

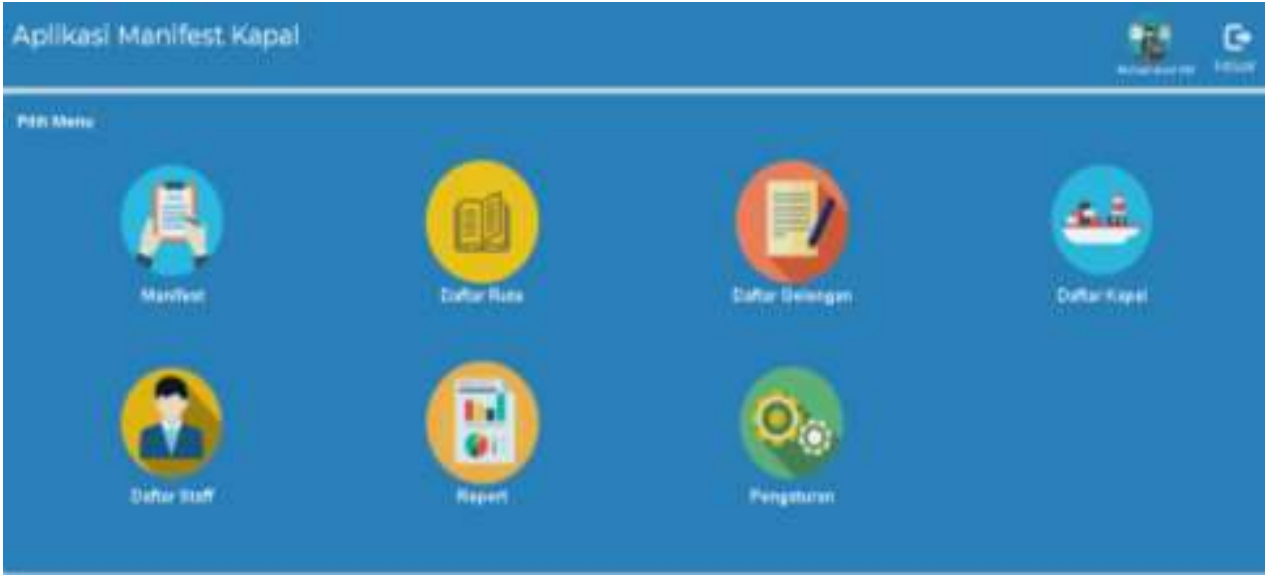

Gambar 8. Halaman Menu Utama Admin

\section{Halaman Daftar Manifest}

Halaman ini merupakan halaman untuk pengelolaan daftar manifest penumpang. Pengguna dapat melakukan proses input data hingga mencetak laporan data manifest melalui halaman ini.

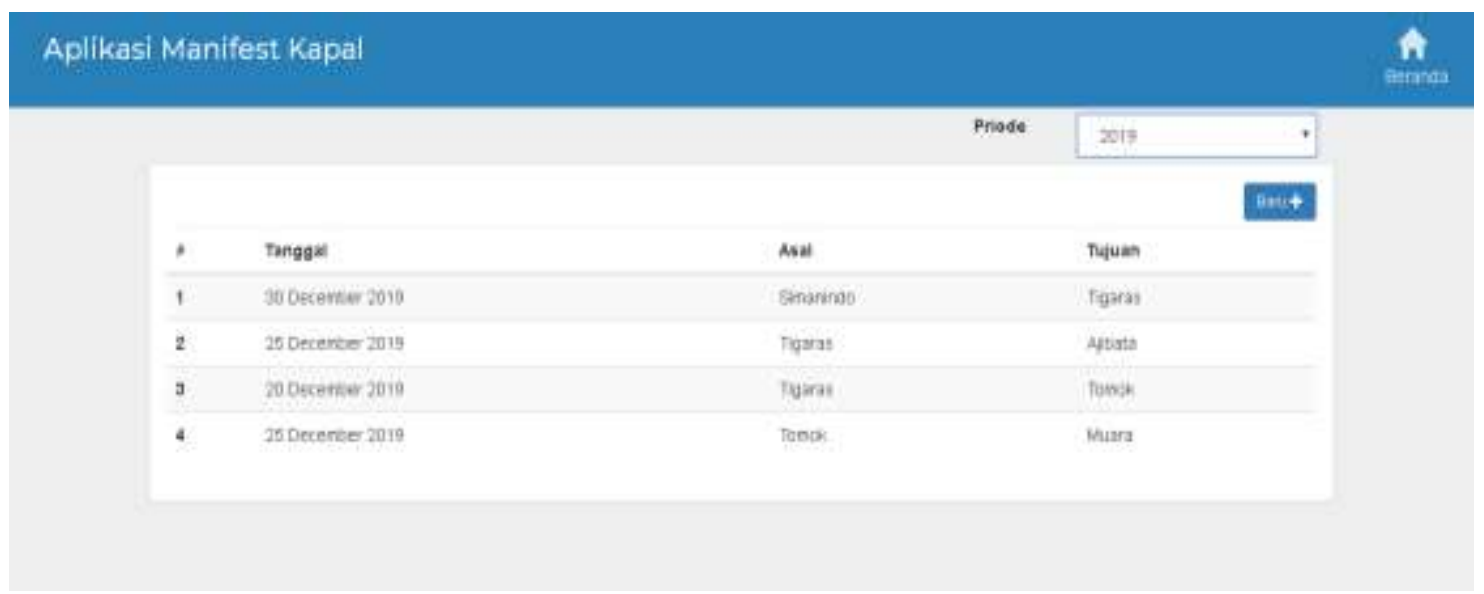

Gambar 9. Halaman Daftar Manifest

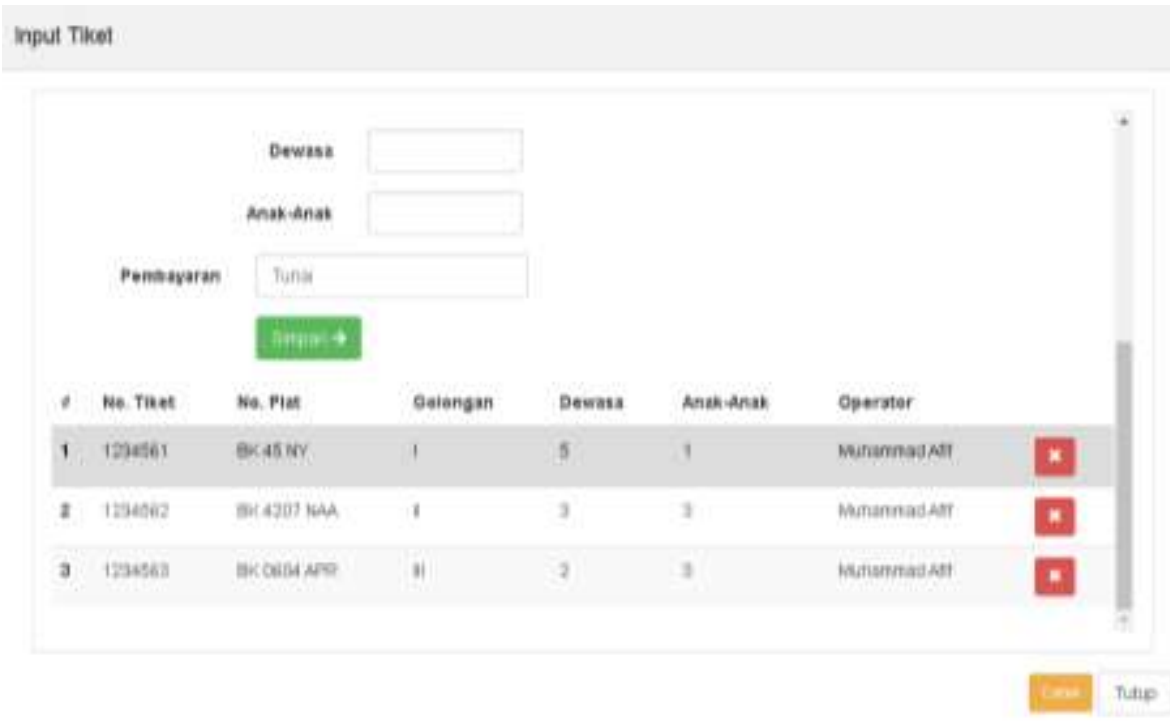

Gambar 10. Halaman Input Data Manifes 
JURNAL MEDIA INFORMATIKA BUDIDARMA

Volume 4, Nomor 1, Januari 2020, Page 237-244

ISSN 2614-5278 (media cetak), ISSN 2548-8368 (media online)

Available Online at https://ejurnal.stmik-budidarma.ac.id/index.php/mib DOI $10.30865 /$ mib.v4i1.1892

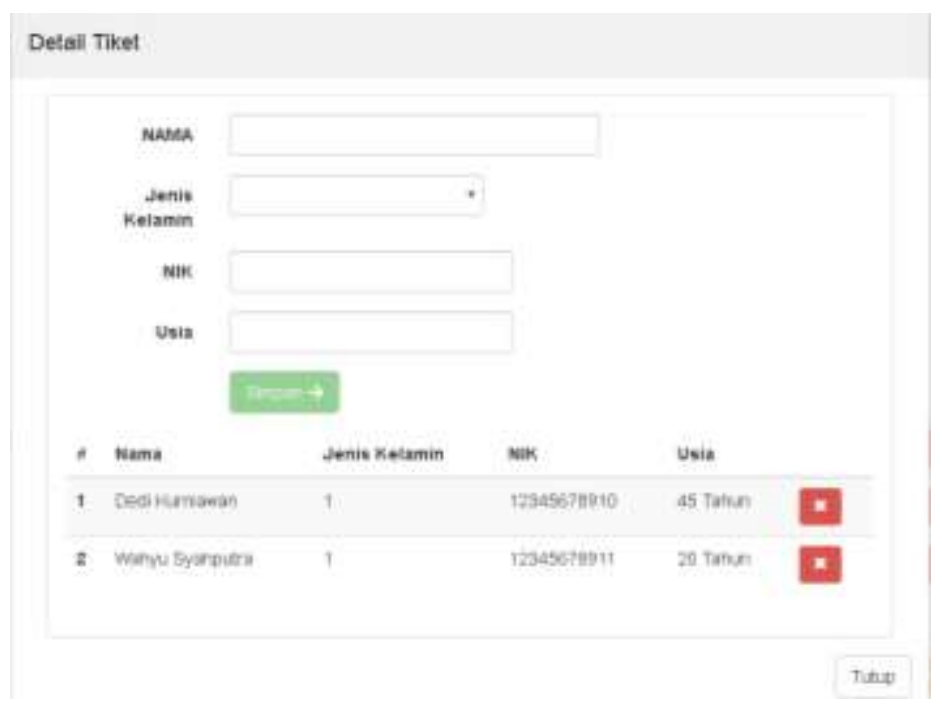

Gambar 11. Halaman Input Data Detail Penumpang

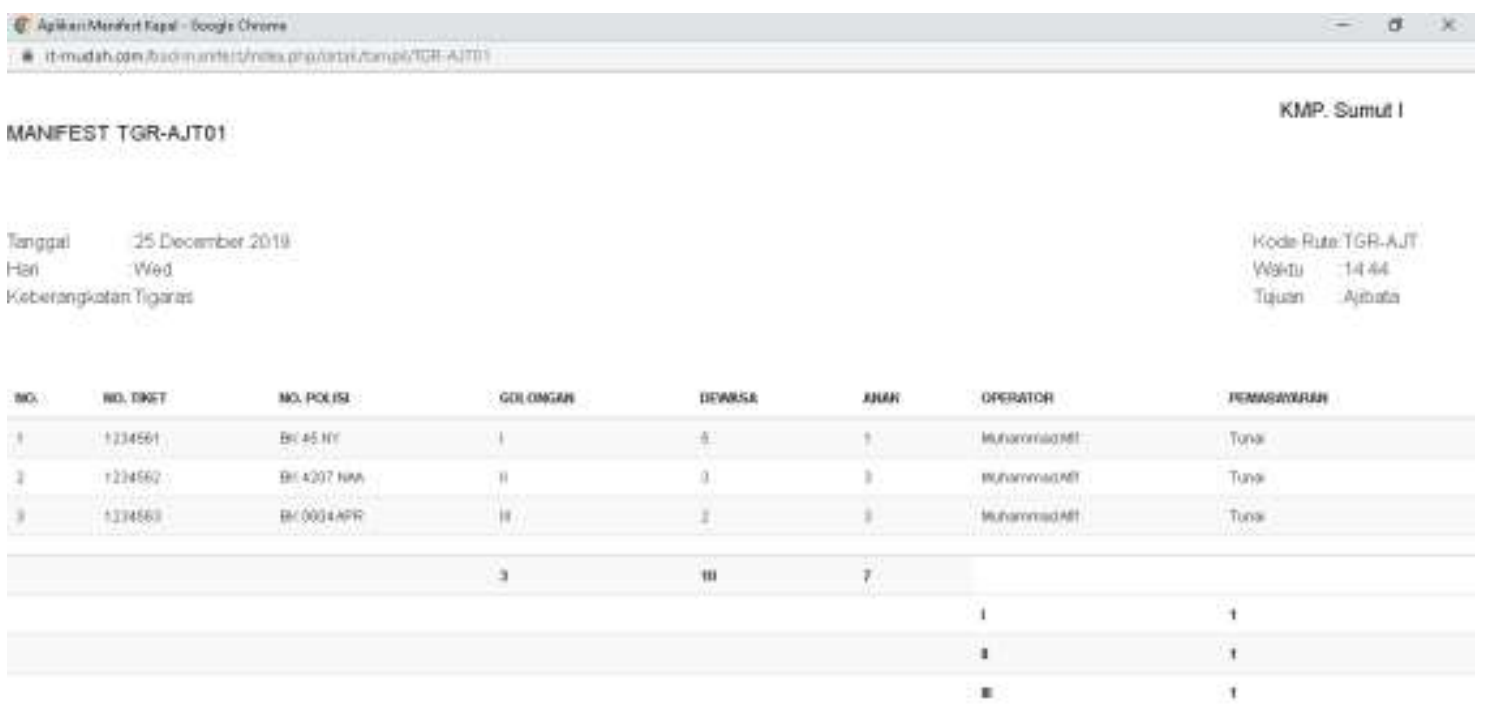

Gambar 12. Halaman Laporan Data Manifes

\section{Halaman Data Rute Kapal}

Halaman ini merupakan halaman untuk pengelolaan data rute kapal. Pengguna dapat melakukan proses input data rute kapal melalui halaman ini.

\section{Aplikasi Manifest Kapal}
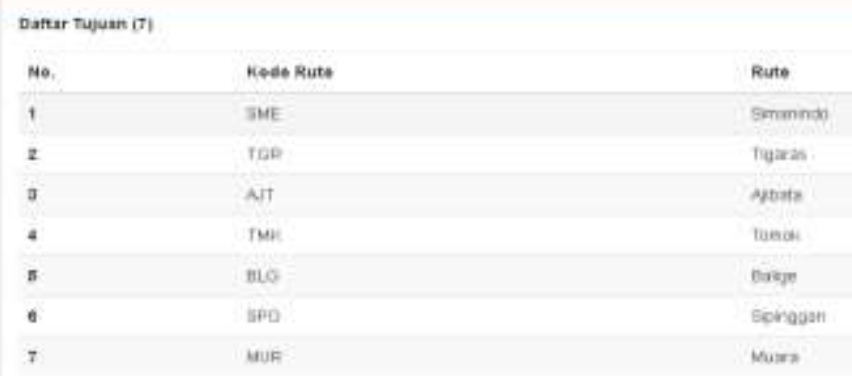

Gambar 13. Halaman Data Rute Kapal

\section{Halaman Data Kapal}

Halaman ini merupakan halaman untuk pengelolaan data kapal. Pengguna dapat melakukan proses input data kapal melalui halaman ini. 


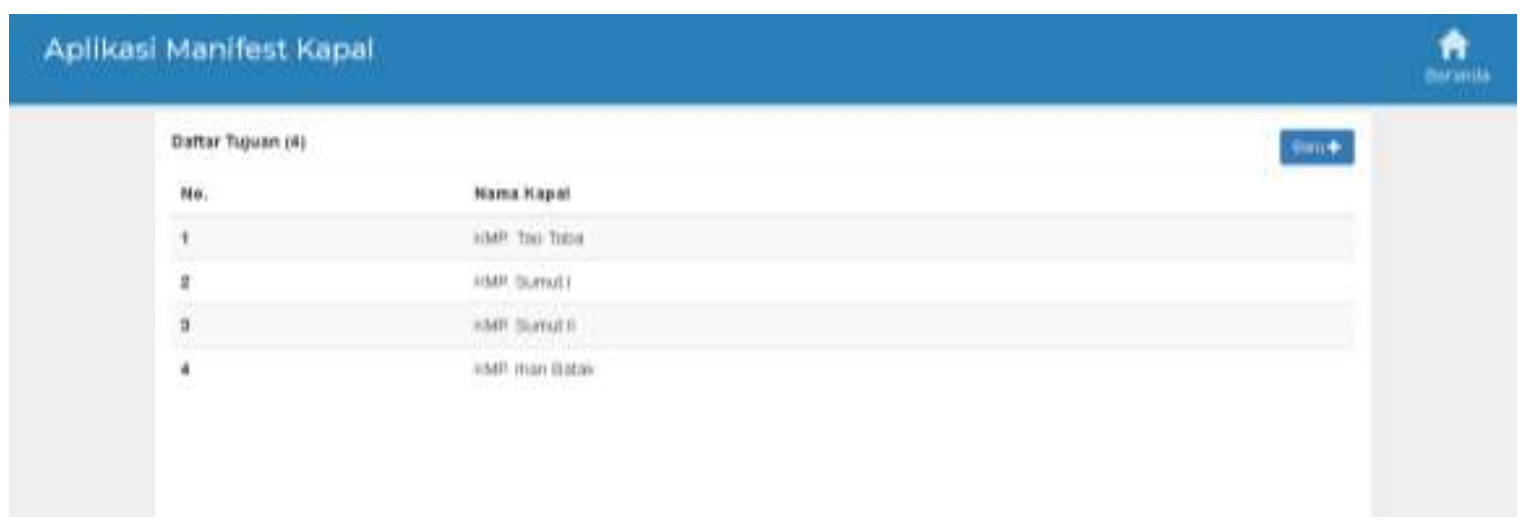

Gambar 14. Halaman Data Kapal

\section{KESIMPULAN}

Penelitian ini telah menghasilkan model UML dan prototype aplikasi pencatatan manifest penumpang kapal penyeberangan di Danau Toba berbasis web berdasarkan data contoh dari Dinas Perhubungan Sumatera Utara dan telah diujikan penggunaannya. Berdasarkan penelitian ini, dapat disimpulkan hal-hal berikut ini:

a. Model UML dapat digunakan dalam memberikan gambaran sistem yang akan dibangun pada desain pencatatan manifest penumpang kapal penyeberangan sehingga proses yang dihasilkan dapat dibaca dengan mudah dengan bantuan penggunaan Use Case Diagram, Sequence Diagram, Activity Diagram, State Diagram dan Deployment Diagram.

b. Aplikasi Pencatatan Manifest Penumpang dapat digunakan untuk mempermudah Dinas Perhubungan Sumatera Utara dalam melakukan pengawasan dan pengontrolan terhadap daftar penumpang kapal yang melakukan perjalanan di Kawasan Danau Toba, sehingga akan dapat mengurangi resiko kecelakaan dan penyalahgunaan jumlah muatan kapal dari yang diizinkan oleh Dinas Perhubungan.

\section{REFERENCES}

[1] Pusat Bahasa Departemen Pendidikan Nasional, Kamus Besar Bahasa Indonesia, xvi. Jakarta: Pusat Bahasa, 2008.

[2] Kementerian Perhubungan RI, "Peraturan Menteri Perhubungan Republik Indonesia Tentang Fasilitas Udara," 2015.

[3] R. A. Siregar, H. W. Wiranegara, and H. Hermantoro, "Pengembangan Kawasan Pariwisata Danau Toba, Kabupaten Toba Samosir," Tataloka, vol. 20, no. 2, p. 100, 2018, doi: 10.14710/tataloka.20.2.100-112.

[4] J. Neo, T. Vol, P. Destinasi, and W. Danau, "Berdasarkan Peraturan Pemerintah No. 50 Tahun 2011 tentang Rencana Induk Pembangunan Kepariwisataan,” vol. 4, no. 1, 2018.

[5] Kementerian Perhubungan RI, "Peraturan Menteri Perhubungan Republik Indonesia No.PM 25 Tahun 2016 Tentang Daftar Penumpang dan Kendaraan Angkutan Penyeberangan.” Kementrian Perhubungan RI, Jakarta, p. 16, 2016.

[6] S. Tjahjono and H. Satmiko, "Laporan Investigasi Kecelakaan Kapal Laut Tenggelamnya KM. Sinar Bangun 4 Tahun 2018," Kementeri. Perhub., pp. 1-53, 2018.

[7] V. Saxena and M. Srivastava, "UML Modeling Performance Evaluation of Multithreaded Programs on Dual Core Processor,” Int. J. Hybrid Inf. ..., vol. 2, no. 3, pp. 1-10, 2009. 